\title{
NOTE
}

\section{KINETICS OF THE OXIDATION OF VITAMIN C}

\author{
Sitti Rahmawati ${ }^{1, *}$ and Bunbun Bundjali ${ }^{2}$ \\ ${ }^{1}$ Chemistry Courses, Mathematics and Natural Educational Sciences Division, Faculty of Teacher Training and Educational \\ Sciences, Tadulako University, Indonesia, Jl. Soekarno Hatta Km 9 Palu 94118 Indonesia \\ ${ }^{2}$ Inorganic and Physical Chemistry Division Faculty of Mathematics and Natural Sciences, \\ Institut Teknologi Bandung, Jl. Ganesha 10 Bandung 40132 Indonesia
}

Received April 9, 2012; Accepted October 31, 2012

\begin{abstract}
Vitamin $C$ or ascorbic acid is needed by the human body but it is already damaged by the rise in temperature due to be oxidized to L-dehydroascorbic acid. This research aims to determine the kinetics of oxidation of ascorbic acid due to an increase if temperature $\left(40-80{ }^{\circ} \mathrm{C}\right)$ and to design an ascorbic acid oxidation reaction laboratory module to be applied in the senior high school reaction kinetics curriculum. The determination of the kinetics of the oxidation of ascorbic acid applies the integral and half-change time methods, while the concentration of the remained ascorbic acid in sixty minute intervals is determined by iodimetric titration method. Decomposition of ascorbic acid was measured at 40,50,60,70 and $80^{\circ} \mathrm{C}$. The results of this research indicate that at 40, 50,60, 70 and $80^{\circ} \mathrm{C}$ the kinetics of the oxidation of ascorbic acid is a first-order reaction with rate constants of $4.55 \times 10^{-4}, 5.85$ $\times 10^{-4}, 8.4 \times 10^{-4}, 1.1 \times 10^{-3}$ and $1.015 \times 10^{-3} \mathrm{~min}^{-1}$, respectively. Pre-exponential factor or the frequency of collisions is a factor which is a measure of the collision rate. The activation energy and the pre-exponential factor for the oxidation of ascorbic acid were found to be $20.73 \mathrm{~kJ} \mathrm{~mol}^{-1}$ and $1.372 \mathrm{~min}^{-1}$. The procedure used in this study was modified into a laboratory module will be applied in the teaching of reaction kinetics at the senior high school level.
\end{abstract}

Keywords: ascorbic acid; kinetic reaction; temperature

\section{ABSTRAK}

Vitamin C atau asam askorbat sangat dibutuhkan oleh tubuh manusia tetapi sangat mudah rusak oleh kenaikan temperatur karena teroksidasi menjadi asam L-dehidroaskorbat. Penelitian ini bertujuan untuk menentukan kinetika reaksi oksidasi vitamin C pada temperatur $40-80{ }^{\circ} \mathrm{C}$ serta merancang eksperimen kinetika reaksi oksidasi vitamin $C$ yang dapat dilakukan di tingkat sekolah menengah atas. Penentuan kinetika reaksi oksidasi vitamin $C$ dilakukan dengan menggunakan metode integral dan grafik sedangkan kadar asam askorbat sisa ditentukan dengan metode titrasi iodimetri tiap interval waktu enam puluh menit. Kerusakan vitamin $C$ diukur pada temperatur 40, 50, 60, 70 dan $80^{\circ} \mathrm{C}$. Hasil penelitian menunjukkan bahwa kinetika reaksi oksidasi vitamin $\mathrm{C}$ mengikuti reaksi orde satu pada temperatur $40,50,60,70$ dan $80^{\circ} \mathrm{C}$ dengan tetapan laju reaksi berturut-turut $4,55 \times 10^{-4}, 5,85 \times 10^{-4}$ , 8,4 × $10^{-4}, 1,1 \times 10^{-3}$ dan 1,015 × $10^{-3}$ menit $^{-1}$. Energi aktivasi dan faktor pre-eksponensial reaksi oksidasi asam

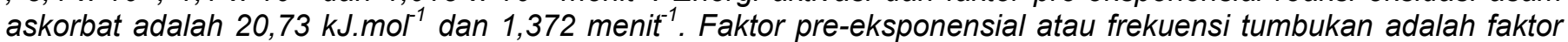
yang merupakan ukuran laju terjadinya tumbukan. Prosedur yang digunakan dalam penelitian ini dimodifikasi ke dalam modul laboratorium untuk diterapkan dalam pengajaran kinetika reaksi pada tingkat SMA

Kata Kunci: Vitamin C; kinetika reaksi; temperatur

\section{INTRODUCTION}

Vitamins are a group of organic complex compounds that the body needs in small quantities. Vitamins must be supplied from outside, as the human body cannot synthesize them. One such vitamin is Vitamin C. The exact amount of Vitamin C that the body needs is unknown, and is thought to be anywhere from 45 to $75 \mathrm{mg}$ a day [1].
Vitamin $\mathrm{C}$, or ascorbic acid, is a vitamin that can be found in various fruits and vegetable. Vitamin $C$ is a white, crystal-shaped organic compound, and can be synthesized from glucose or extracted from certain natural sources such as orange juice. The vitamin was first isolated from lime juice by Szent Gyorgy in 1928 [2].

Vitamin C plays a vital role in our lives; Firstly, it contributes in to the synthesis of collagen tissue around

* Corresponding author. Tel/Fax : +62-85241111314

Email address : sittirahmawati@yahoo.com 
bones, teeth, cartilage, skin, and damaged tissue. Second, this vitamin is needed to activate various enzymes related to the nervous system, hormones, and detoxification of medicine and poison in the liver. Third, its role as an antioxidant is well-known in society; its solubility enables it to work as antioxidant within our bodily fluids. Fourth, Vitamin $C$ increases the rate of absorption of iron, calcium, and folic acid. Fifth, it reduces allergic reactions, boosts the immune system, stimulates the formation of bile in the gallbladder, and facilitates the excretion of various steroids [3]. Vitamin C is important in the functioning of the brain, as the brain contains a large amount of Vitamin C. A study by two researchers at the Texas Woman's University found that high school students with high blood Vitamin $C$ rates produced better IQ test compared to students with low rates.

Fruits and vegetables, like oranges, greens, tomatoes, potatoes, and berries are the main source of Vitamin $\mathrm{C}$ for humans.

Vitamin C is highly soluble in water and alcohol, and is easily oxidized. The oxidation of Vitamin C occurs very quickly in a base environment at high temperatures. "Light and heat damage Vitamins $B$ and $C$ in fruits and vegetables. Vitamin $B$ and $C$ also decreases if food is left warm or hot for to long" [4]. This is often inevitable in the processing of food that contains Vitamin C such as fruits and vegetables.

The important role of Vitamin C in metabolism has resulted in a plethora of research, among others: The determination of the amount of Vitamin $C$ in various drinks using the redox titration method. This method produces accurate results, despite the low levels of ascorbic acid present [5]. The determination of the amount of Vitamin $C$ in various fruits and vegetables also can be done by bipotentiometric iodimetric titration method. This method produces efficient ascorbic acid quantification at relatively low prices with cheap equipment [6]. Comparisons between the iodimetric and visible spectrophotometric methods of Vitamin C determination show that spectrophotometry is less viable, as it is more expensive and time-consuming than iodimetry with insignificant differences in accuracy [7]. The effect of storage at room temperature on the amount of Vitamin $\mathrm{C}$, show that the amounts is significantly reduced if it is stored at room temperature [8]. Vitamin C levels decrease significantly at room temperature it is necessary to determine the kinetics of the oxidation of vitamin C.

Based on the above results, the authors were interested to further study the effect of heating, at various temperatures, on the kinetics of the oxidation of Vitamin C, using iodimetric titration method in determining the amount of Vitamin $\mathrm{C}$ present.

\section{EXPERIMENTAL SECTION}

\section{Materials}

Materials used in this study were Vitamin C p.a, $0.01 \mathrm{~N}$ lodine solution, $\mathrm{Kl}, 1 \%$ starch solution, and deionized water.

\section{Instrumentation}

Equipments used in this study, were Erlenmeyer, measuring glass, chemical glass, Petridish, measuring flask, stirring rod, analytic scale, burette, funnel, volume pipette, pipette, stand and clamp, oven, timekeeper, and spray bottle.

\section{Procedure}

\section{Provision of material}

Solutions used in this study, among others were $0.01 \mathrm{~N}$ lodine solution, $1 \%$ starch solution.

The $0.01 \mathrm{~N}$ lodine solution was made by adding $23 \mathrm{~g}$ of $\mathrm{Kl}$ to $1.27 \mathrm{~g}$ of powdered lodine, dissolving it in $25 \mathrm{~mL}$ of deionized water, and transporting it into a $1000 \mathrm{~mL}$ measuring flask before adding deionized water up to the mark [9-10].

The $1 \%$ starch solution was made by dissolving $1 \mathrm{~g}$ of starch in $100 \mathrm{~mL}$ of hot water. This solution was used as the indicator.

\section{Determination of the oxidation reaction kinetics of vitamin C}

Ascorbic acid $0.5 \mathrm{~g}$ dissolved with deionized water in a $100 \mathrm{~mL}$ measuring flask. 6 cleaned Erlenmeyer are then taken and labeled from $A$ to $F$. Each Erlenmeyer is filled with $5 \mathrm{~mL}$ of ascorbic acid. Vitamin C in Erlenmeyer B, C, D, E, and F are heated at $40{ }^{\circ} \mathrm{C}$ in $60 \mathrm{~min}$ increments $(60 \mathrm{~min}$ for Erlenmeyer B, $120 \mathrm{~min}$ for Erlenmeyer C, $180 \mathrm{~min}$ for Erlenmeyer D, $240 \mathrm{~min}$ for Erlenmeyer $\mathrm{E}$, and $300 \mathrm{~min}$ for Erlenmeyer $F$ ). This is followed by the determination of Vitamin $C$ rates in each sample (Erlenmeyer A, B, C, D, $\mathrm{E}$, and $\mathrm{F}$ ) through the titration of $5 \mathrm{~mL}$ of Vitamin $\mathrm{C}$ solution with a lodium $0.01 \mathrm{~N}$ solution, and a $1 \%$ Starch solution as the indicator, Blue indicates the end of the titration.

This method is repeated at various temperatures $50,60,70$, and $80^{\circ} \mathrm{C}$ and ascorbic acid concentrations.

\section{Data analysis}

Determination of vitamin C rates. Vitamin C oxidation rates can be determined through the titration of an $\mathrm{I}_{2}$ $0.01 \mathrm{~N}$ solution with a $1 \mathrm{~mL}$ starch indicator. $1 \mathrm{~mL} \mathrm{I}$ solution $0.01 \mathrm{~N}=0.88 \mathrm{mg}$ Vitamin $\mathrm{C}$ [10]. 
Table 1. Ascorbic acid percentages at time $t$ for $\mathrm{T}=40,50,60,70$, and $80{ }^{\circ} \mathrm{C}$

\begin{tabular}{cccccccc}
\hline Temperature & Ascorbic acid first & \multicolumn{5}{c}{$\%$ ascorbic acid left in heating process for (min) } \\
\cline { 3 - 7 }$\left({ }^{\circ} \mathrm{C}\right)$ & concentration $(\mathrm{M})$ & 0 & 60 & 120 & 180 & 240 & 300 \\
\hline 40 & 0.0142 & 100 & 97.535 & 94.718 & 92.254 & 89.437 & 87.324 \\
& 0.0284 & 100 & 97.432 & 94.267 & 92.156 & 89.694 & 87.056 \\
50 & 0.0142 & 100 & 95.774 & 91.549 & 88.028 & 85.916 & 83.451 \\
& 0.0284 & 100 & 95.599 & 91.373 & 87.676 & 85.035 & 83.099 \\
60 & 0.0142 & 100 & 95.070 & 90.845 & 86.972 & 83.451 & 80.282 \\
& 0.0284 & 100 & 92.606 & 90.141 & 86.796 & 82.746 & 79.578 \\
70 & 0.0142 & 100 & 90.845 & 87.324 & 83.099 & 81.690 & 78.873 \\
& 0.0284 & 100 & 90.141 & 86.972 & 84.507 & 81.338 & 78.521 \\
80 & 0.0142 & 100 & 95.422 & 86.620 & 82.394 & 78.873 & 77.113 \\
& 0.0284 & 100 & 93.662 & 86.268 & 82.042 & 77.993 & 75.704 \\
\hline
\end{tabular}

Determination of reaction order and reaction rate constant. The kinetics of the oxidation reaction of Vitamin C which covers its reaction order, reaction rate constant, and activation energy are determined through observation. The half-time method is used to determine the reaction's order and reaction rate constant. The halftime method uses Equations 1, 2, and 3. The activation energy is determined through Equation 4.

$$
\begin{aligned}
& \frac{\left(t \frac{1}{2}\right)_{1}}{\left(t \frac{1}{2}\right)_{2}}=\left(\frac{a_{2}}{a_{1}}\right)^{n-1} \\
& \frac{t_{x \%}}{t_{50 \%}}=\frac{\frac{1}{k}\left(\ln \frac{\left[A_{0}\right]}{\left[A_{x}\right]}\right)}{\frac{1}{k}\left(\ln \frac{100}{50}\right)} \text { for first reaction order } \\
& \frac{t_{x \%}}{t_{50 \%}}=\frac{\frac{1}{k}\left(\frac{1}{\left[A_{x}\right]}-\frac{1}{\left[A_{0}\right]}\right)}{\frac{1}{k}\left(\frac{1}{50}-\frac{1}{100}\right)} \text { for second reaction order } \\
& \text { In } k=\left(-\frac{E_{a}}{R}\right)\left(\frac{1}{T}\right)+\ln A \\
& y=m x+b
\end{aligned}
$$

\section{RESULT AND DISCUSSION}

The lodimetric Titration method by direct titration with a standard lodine solution was used to determine Vitamin $C$ oxidation reaction kinetics. This method is effective as Vitamin $C$ is easily oxidized and lodine is easily reduced. To avoid the dissipation of lodine through evaporation, lodine is reacted with $\mathrm{KI}$ to form Tri-iodide ions $\left(\mathrm{I}_{3}^{-}\right)$, rendering iodine dissipation negligible (with at least $4 \% \mathrm{KI}$ ) [9]. The standardization of the iodine solution is unnecessary; as the water content in ascorbic acid is very low, the error produced is still within the tolerance limits of the titration method [11].

If in the acidic solution containing both Vitamin $C$ and carbohydrates (from starch as an indicator) are added with lodine, Vitamin C oxidized, the lodine is reduced, than the solution turns to purple. This color change is the basis will be of the titration reaction, and the purple indicates the end of the reaction process [12]. From this titration the amount (in $\mathrm{mL}$ ) of iodine solution used, is obtained which is equivalent to the concentration of the ascorbic acid remained in each 60 min interval sample (Erlenmeyer $A$ to $F)$. (1 $\mathrm{mL}$ of $0.01 \mathrm{~N} \mathrm{I}_{2}$ solution $=0.88 \mathrm{mg}$ of ascorbic acid)

$$
\begin{aligned}
& \mathrm{C}_{6} \mathrm{H}_{8} \mathrm{O}_{6} \rightarrow \mathrm{C}_{6} \mathrm{H}_{6} \mathrm{O}_{6}+2 \mathrm{H}^{+}+2 \mathrm{e} \\
& \frac{\mathrm{I}_{2}+2 \mathrm{e} \rightarrow 2 \mathrm{I}^{-}}{\mathrm{C}_{6} \mathrm{H}_{8} \mathrm{O}_{6}+\mathrm{I}_{2} \rightarrow \mathrm{C}_{6} \mathrm{H}_{6} \mathrm{O}_{6}+2 \mathrm{H}^{+}+2 \mathrm{I}^{-}}
\end{aligned}
$$

As each ascorbic acid molecule loses 2 electrons through titration, its equivalent weight is half of it's the molecular weight, $88.07 \mathrm{~g} / \mathrm{ek}$.

This study has determined the concentration of ascorbic acid at various temperatures $(40,50,60,70$, and $80{ }^{\circ} \mathrm{C}$ ) in 60 min intervals. The concentrations of ascorbic acid can then be used to determine the reaction order and reaction rate constant of the oxidation reaction of ascorbic acid at various temperatures.

\section{Determination of the Reaction Velocity Constant and Reaction Order of the Oxidation Reaction of Ascorbic Acid}

Table 1 shows the results of determination of the reaction rate constant and order of Vitamin $\mathrm{C}$ oxidation at $40,50,60,70$, and $80^{\circ} \mathrm{C}$.

Based on this data, the reaction rate constant and order can be determined with the half-time method; the various initial-remain ascorbic acid percentage values, with time intervals t substituted into Equations 2 and 3. These calculations can be found in Table 2 .

From Table 2 it can be seen that the data for the initial concentrations of both $0.0412 \mathrm{M}$ and $0.0284 \mathrm{M}$ ascorbic acid tend to be constant; therefore half-time is independent on initial concentration and initial value. Based on Table 2, the half-time is between 
Table 2. Half-time at various temperatures and time intervals for a first order reaction

\begin{tabular}{ccccccc}
\hline Temperature & Ascorbic acid first & \multicolumn{5}{c}{ Acid Half-time at each time interval of $\mathrm{t}$} \\
\cline { 3 - 6 } & concentration $(\mathrm{C})$ & 60 & 120 & 180 & 240 & 300 \\
\hline 40 & 0.0142 & 1666.1 & 1532.5 & 1547.1 & 1489.8 & 1533.8 \\
& 0.0284 & 1598.5 & 1408.5 & 1527.1 & 1529.1 & 1499.8 \\
50 & 0.0142 & 963.1 & 941.9 & 978.3 & 1095.6 & 1149.2 \\
& 0.0284 & 923.8 & 921.8 & 948.4 & 1026.0 & 1122.9 \\
60 & 0.0142 & 822.5 & 866.1 & 893.6 & 919.3 & 946.6 \\
& 0.0284 & 541.3 & 801.2 & 880.9 & 878.2 & 910.1 \\
70 & 0.0142 & 433.1 & 613.5 & 673.8 & 822.4 & 876.0 \\
& 0.0284 & 400.6 & 595.8 & 741.0 & 805.2 & 859.8 \\
80 & 0.0142 & 887.4 & 578.9 & 644.1 & 700.8 & 799.9 \\
& 0.0284 & 635.0 & 563.0 & 630.2 & 669.2 & 746.9 \\
\hline
\end{tabular}

Table 3. Reaction order calculation based on the half-time method at $40^{\circ} \mathrm{C}$

\begin{tabular}{cccccc}
\hline \multirow{2}{*}{ Time (t) } & \multicolumn{5}{c}{ Reaction Order $(\mathrm{n})$ at temperature of $40{ }^{\circ} \mathrm{C}$} \\
\cline { 2 - 6 } & $40{ }^{\circ} \mathrm{C}$ & $50{ }^{\circ} \mathrm{C}$ & $60{ }^{\circ} \mathrm{C}$ & $70{ }^{\circ} \mathrm{C}$ & $80{ }^{\circ} \mathrm{C}$ \\
\hline 60 & 1.060 & 1.060 & 1.603 & 1.112 & 1.483 \\
120 & 1.122 & 1.031 & 1.112 & 1.042 & 1.040 \\
180 & 1.019 & 1.045 & 1.021 & 0.863 & 1.031 \\
240 & 0.962 & 1.095 & 1.066 & 1.030 & 1.067 \\
300 & 1.032 & 1.033 & 1.057 & 1.027 & 1.099 \\
\hline
\end{tabular}

Table 4. Velocity constant of the oxidation reaction of ascorbic acid at various temperatures and time intervals

\begin{tabular}{ccccccc}
\hline \multirow{2}{*}{ No. } & \multirow{2}{*}{$(\mathrm{min})$} & \multicolumn{4}{c}{ The value of reaction rate constant, $k\left(\mathrm{~min}^{-1}\right)$ at temperature of } \\
\cline { 3 - 6 } & & $40^{\circ} \mathrm{C}$ & $50{ }^{\circ} \mathrm{C}$ & $60^{\circ} \mathrm{C}$ & $70^{\circ} \mathrm{C}$ & $80{ }^{\circ} \mathrm{C}$ \\
\hline 1 & 60 & 0.00043 & 0.00060 & 0.00106 & 0.00167 & 0.00094 \\
2 & 120 & 0.00047 & 0.00063 & 0.00083 & 0.00115 & 0.00122 \\
3 & 180 & 0.00045 & 0.00059 & 0.00079 & 0.00099 & 0.00107 \\
4 & 240 & 0.00046 & 0.00057 & 0.00077 & 0.00085 & 0.00096 \\
5 & 300 & 0.00046 & 0.00054 & 0.00075 & 0.00080 & 0.00090 \\
& average & $\mathbf{0 . 0 0 0 4 5}$ & $\mathbf{0 . 0 0 0 5 9}$ & $\mathbf{0 . 0 0 0 8 4}$ & $\mathbf{0 . 0 0 1 0 9}$ & $\mathbf{0 . 0 0 1 0 2}$ \\
\hline
\end{tabular}

650-1500 min; much longer than the data gathered $300 \mathrm{~min}$. Thereafter, the integration method was used to obtain the reaction's order, and it was found that on the $0^{\text {th }}, 1^{\text {st }}$, and $2^{\text {nd }}$ orders the reaction's rate constant tended to be constant, and the regression coefficient tended to be linear. Hence, the integration method has failed to find the reaction's order with a total combined time of $300 \mathrm{~min}$. The alternative we uses the half-time method to determine the oxidation reaction of ascorbic acid's reaction order. The results of are shown in Table 3, based upon data from Table 2 and by using Equation 1 .

Data from Table 3 shows a first order reaction. Hence, the oxidation reaction of ascorbic acid is a first order reaction. This result is consistent with previous research: 1) Research investigating ascorbic acid degradation kinetics, using titration with 2,6dychlorophenol indophenol, suggests a first order reaction for temperatures between 4 and $5{ }^{\circ} \mathrm{C}$ [13]. 2) Vitamin $\mathrm{C}$ degradation determined using the potentiometric method at 37.8 and $46.1^{\circ} \mathrm{C}$ also suggests a first order reaction [14]. 3) Vitamin C degradation kinetics in storage at temperatures between 25 and 45 ${ }^{\circ} \mathrm{C}$ in $5{ }^{\circ} \mathrm{C}$ intervals, respectively, with Vitamin $\mathrm{C}$ concentration determined through titration with 2,6dychlorophenol, suggests a first order reaction [15].

By entering data from Table 1 into the first order reaction velocity equation, the value of the reaction velocity constant can be determined:

$\mathrm{kt}=\ln \frac{\mathrm{a}}{(\mathrm{a}-\mathrm{x})}$

where $a$ is the (percent) initial concentration of ascorbic acid and $(a-x)$ the (percent) ascorbic acid remaining after each time interval. The calculations results are shown in Table 4.

Based on these calculations, the rate constants at $40,50,60,70$, and $80{ }^{\circ} \mathrm{C}$ are $0.00045,0.00059$, $0.00084,0.00109$, and 0.00102 unit respectively.

\section{Activation Energy and Pre-exponential Factor Determination}

The reaction rate constant data from Table 4 shows that the rate constant $(k)$ rises with temperature. This is consistent with the Arrhenius Theory. Increase in temperature also increases the kinetic energy of the substance. The activation energy of the oxidation reaction of Vitamin C can be determined based on data 
Table 5. Basic Competence, Learning Activities, and Indicators of reaction kinetics study in high school

\begin{tabular}{|c|c|c|}
\hline Basic Competence & Learning Activities & Indicators \\
\hline $\begin{array}{l}\text { Describing and understanding } \\
\text { reaction rate through an } \\
\text { experiment investigating the } \\
\text { factors that influence reaction } \\
\text { rate. }\end{array}$ & $\begin{array}{l}\text { - Calculating and making a solution of a } \\
\text { specific concentration in groups, in the } \\
\text { laboratorium. } \\
\text { - Designing and conducting and } \\
\text { experiment to investigate the factors } \\
\text { that influence reaction rate, in the } \\
\text { laboratorium } \\
\text { - Concluding the factors that determine } \\
\text { reaction rate. }\end{array}$ & $\begin{array}{l}\text { - Calculating the concentration of a } \\
\text { solution (solution molarity) } \\
\text { - Analyzing the factors that influence } \\
\text { reaction rate (concentration, surface } \\
\text { area, temperature, and catalysts) } \\
\text { through experimentation. } \\
\text { - Plotting a graph from experimental } \\
\text { data regarding the factors that } \\
\text { influence reaction rate. }\end{array}$ \\
\hline
\end{tabular}

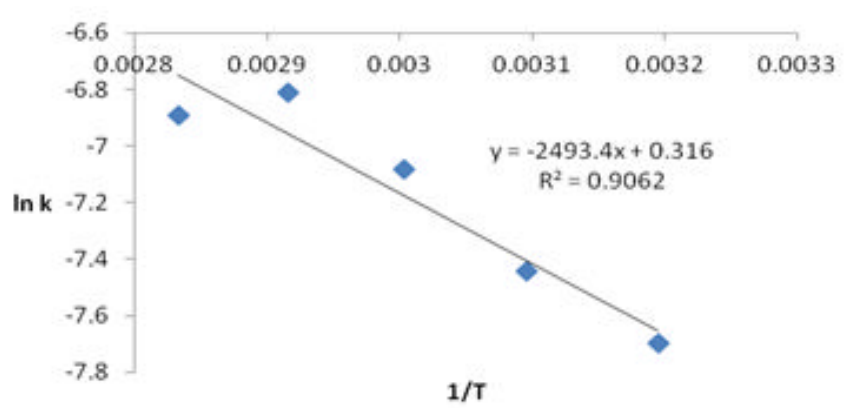

Fig 1. The relation between $\mathrm{In} \mathrm{k}$ and $1 / \mathrm{T}$ in the oxidation reaction of ascorbic acid

from Table 4 and using Equation 4. Plotting In $k$ against $\frac{1}{\mathrm{~T}}$ gives Fig. 1 .

Fig. 1 shows the regression equation $y=0.316-$ $2493 x$ with $\mathrm{R}^{2}=0.906$. Based on the regression equation, pre-exponential factor of $1.372 \mathrm{~min}^{-1}$ and

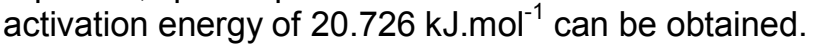

$$
\begin{array}{rlrl}
\text { In } \mathrm{k} & =\left(-\frac{E_{a}}{R}\right) \frac{1}{T}+\ln \mathrm{A} & & \\
\mathrm{y} \quad=\mathrm{mx}+\mathrm{b} & -\frac{E_{a}}{R} & =-2493 \\
y \quad & =-2493 \mathrm{x}+0.316 & E_{a} & =2493 \mathrm{~K} \times 8.314 \mathrm{~J} \cdot \mathrm{K}^{-1} \cdot \mathrm{mol}^{-1} \\
\text { In } \mathrm{A} & =0.316 & & =20726.8 \mathrm{~J} \cdot \mathrm{mol}^{-1} \\
\mathrm{~A} & =1.372 & & =20.73 \mathrm{~kJ} \cdot \mathrm{mol}^{-1}
\end{array}
$$

So the relation of reaction rate constant and activation energy for Vitamin $\mathrm{C}$ oxidation reaction can be written as:

$k=13.32^{\mathrm{e}^{\frac{20.73}{R T}}}$

Activation energy of vitamin $\mathrm{C}$ oxidation reaction of $20.73{\mathrm{~kJ} . \mathrm{mol}^{-1}}^{-1}$ shows that reaction rate constant changes with energy of $20.73 \mathrm{~kJ}^{-\mathrm{mol}^{-1}}$ towards the temperature. Pre-exponential factor of $1.372 \mathrm{~min}^{-1}$ means that the rate of the collision of $20.73 \mathrm{~kJ}^{-\mathrm{mol}^{-1}}$ or collision factor that has energy of $20.73 \mathrm{~kJ} \mathrm{~mol}^{-1}$ that can produce reaction is $1.372 \mathrm{~min}^{-1}$.

\section{Designing a Reaction Kinetics Lab Module for High School}

Reaction Kinetics is taught on first semester of the second year of high school with previous knowledge of reaction kinetics, chemical balance and the factors that influence it, and its application in everyday life and industry. It is allocated 4 teaching hours, with basic competence and indicators to be fulfilled displayed in Table 5.

Learning material and some reaction kinetics core modules have been designed based on Table 5 . Specifically, the lab module has been designed to include the creation of an ascorbic acid solution at varying concentrations, the effects of concentration and temperature on the reaction rate of the oxidation reaction of ascorbic acid, and the plotting of experimental data on a graph.

\section{CONCLUSION}

The result of the research shows that oxidation reaction kinetic of vitamin $\mathrm{C}$ follows the first order reaction at temperature of $40,50,60,70$ and $80^{\circ} \mathrm{C}$ with values of reaction rate constant respectively $4.55 \times 10^{-4}$, $5.85 \times 10^{-4}, 8.4 \times 10^{-4}, 1.1 \times 10^{-3}, 1.015 \times 10^{-3} \mathrm{~min}^{-1}$ with activation energy of $20.73 \mathrm{~kJ} \mathrm{~mol}^{-1}$, pre-exponential factor $1.372 \mathrm{~min}^{-1}$. Study the module that has been made is referring to curriculum of chemistry KTSP (curriculum level of set of education) 2006 which is now used in high schools, thus it's expected to be able to help the teachers in chemical reaction kinetic study. For the next research, it is suggested for oxidation reaction kinetic of Vitamin $\mathrm{C}$ determination in fruits and vegetables using another method, for example "Clock Reaction" method and also with longer time interval. Designing the determination of reaction kinetic using computer should be used in high school. 


\section{REFERENCES}

1. DeMan, J.M., 1997, "Principles of Food Chemistry", in Kimia Makanan, Kosasih Padmawinata Institut Teknologi Bandung, Bandung, 408-414.

2. Marsetyo dan Kartasaputa, 2004, IImu Gizi Korelasi Gizi, kesehatan dan produktifitas Kerja, Rineka Cipta, Jakarta, 78-80.

3. Nurfatimah, 2008, Konsumsi Vitamin C "Majalah Percikan iman", www.percikaniman.com/mapi/indeks.phd.html, accessed at February 12, 2008

4. Wills, J., 2008, Supaya Bahan Makanan Tidak Kehilangan Gizi "Dinas Kesehatan Jawa Timur" Artikel, www.dinkesjatim.co.id/berita-detail.html /berita-detail.html, accessed at February 13, 2008]

5. Sigmann, S.B., and Wheeler, D.E., 2004, J. Chem. Educ., 81, 7, 1479-1481.

6. Verdini, R.A., and Lagier, C.M., 2004 J. Chem. Educ., 81, 7, 1482-1485.

7. Saputro, D.E., 2005, Perbandingan Metode Penetapan Kadar Vitamin C secara lodometri dan
Spektroskopi Visibel Menggunakan Pereaksi FolinCioucalteu, UMS digital library, Surakarta.

8. Tawali, A.B., and Zainal, 2004, Jurnal Sains dan Teknologi, 4, 3, 130-138.

9. Bassett, J., Denney, R.C., Jeffery, G.H., and Mendham, J., 2003, "Quantitative Analysis Anorganic" in Buku Ajar Vogel Kimia Analisis Kuantitatif Anorganik, Aloysius Hadyana Pudjaatmaka, Erlangga, Jakarta, 433-443.

10. Underwood, A.L., and Day, R.A., 1989, Quantitative Analysis $5^{\text {th }}$ ed., in Analisis Kimia Kuantitatif,, Aloysius Hadyana Pudjaatmaka, Erlangga, Jakarta, 645-647.

11. Hawkes, S.J., 2000, J. Chem. Educ., 77, 12, 1557.

12. Sowa, S., and Kondo, A.E., 2003, J. Chem. Educ., $80,5,550-551$.

13. Abbasi, M., and Niakousari, M., 2007, Electron. J. Environ. Agric. Food Chem., 6, 1, 1735-1741.

14. Nagy, S., and Smoot, J.M., 1997, J. Agric. Food Chem., 25, 1, 135-138.

15. Mazin, M.I., Al-Zubaidy, and Khalii, R.A., 2007, J. Food Chem., 101, 1, 254-259. 